\title{
Kajian Daya Dukung Lahan dan Keberlanjutan Pertanian di Desa Duren Kecamatan Bandungan Kabupaten Semarang
}

\author{
Sudrajat ${ }^{1}$, Suhendra ${ }^{2}$ dan Arifia Mawardani ${ }^{3}$
}

${ }^{1}$ Departemen Geografi Lingkungan, Fakultas Geografi, Universitas Gadjah Mada, Indonesia. ${ }^{2}$ Mahasiswa S2 Ilmu Lingkungan Sekolah Pascasarjana, Universitas Gadjah Mada, Indonesia ${ }^{3}$ Mahasiswa S2 Ilmu Lingkungan Sekolah Pascasarjana, Universitas Gadjah Mada, Indonesia.

Email Koresponden: sdarajat@ugm.ac.id

Direvisi: 2018-06-02 Diterima: 2019-07-24

(C2019 Fakultas Geografi UGM dan Ikatan Geograf Indonesia (IGI)

\begin{abstract}
Abstrak: Daya dukung lahan pertanian merupakan salah satu komponen penting dalam menentukan keberlanjutan pertanian. Hal ini terjadi karena tanpa adanya dukungan lahan pertanian maka keberlanjutan pertanian tidak akan dapat dipertahankan. Berdasarkan hal tersebut maka penelitian ini dilakukan dengan tujuan untuk mengkaji daya dukung lahan pertanian dan keberlanjutan pertanian di Desa Duren Kecamatan Bandungan Semarang. Jumlah sampel yang diambil sebanyak 92 rumahtangga tani secara random sampling. Data terdiri dari data primer dan data sekunder. Pengukuran daya dukung lahan pertanian dilakukan secara kuantitatif, sedangkan pengukuran keberlanjutan pertanian dilakukan secara kualitatif dengan skala likerts dan dianalisis dengan metode kuartil (Q). Hasil analisis daya dukung lahan pertanian menunjukkan bahwa lahan pertanian tidak lagi mendukung terhadap kehidupan petani, namun dari sisi keberlanjutannya masih menunjukkan tinggi. Hal ini terlihat dari hasil analisis keberlanjutan pertanian, dari 5 (lima) dimensi keberlanjutan, hanya 1 (satu) dimensi yang tergolong rendah yaitu dimensi sosal, sedangkan dimensi ekonomi, dimensi lingkungan, dimensi kelembagaan dan dimensi teknologi masih tergolong tinggi dalam mendukung keberlanjutan pertanian..
\end{abstract}

Kata Kunci: Lahan, Pertanian, Daya Dukung, Keberlanjutan

Abstract: Carrying capacity of agricultural land is one important component in determining agricultural sustainability. This happens because without the carrying capacity of agricultural land, the sustainability of agriculture will not be maintained. Based on this, this research was conducted with the aim for analyze the carrying capacity of agricultural land and agricultural sustainability in the Duren Village Bandungan District, Semarang. The number of samples taken was 92 farming households by random sampling. Data consists of primary data and secondary data. Measurement of the camying capacity of agricultural land is done quantitatively, while the measurement of agricultural sustainability is done qualitatively with a Likerts scale and analyzed by the quartile $(Q)$ method. The results of the analysis of the carrying capacity of agricultural land indicate that agricultural land no longer supports the lives of farmers, but in terms of sustainability it still shows high. This can be seen from the results of the analysis of agricultural sustainability, from 5 (five) dimensions of sustainability, only 1 (one) dimension which is classified as low namely social dimension, while the economic dimension, environmental dimension, institutional dimension and technological dimension are still relatively high in supporting agricultural sustainability.

\section{PENDAHULUAN}

Lahan pertanian dari tahun ke tahun terus mengalami penurunan sejalan dengan meningkatnya jumlah penduduk. Pertambahan jumlah penduduk yang tidak diimbangi dengan ketersediaan lahan menyebabkan meningkatnya tekanan penduduk terhadap lahan pertanian. Meningkatnya tekanan penduduk terhadap lahan pertanian telah menjadi permasalahan dalam pembangunan pertanian di suatu wilayah (Moniaga 2011; Trisilia 2014 \& Sudrajat 2016). Salah satu permasalahan meningkatnya tekanan penduduk terhadap lahan pertanian adalah munculnya persaingan di masyarakat dalam memanfaatkan lahan. Akibatnya, beberapa wilayah dengan kepadatan penduduk yang tinggi telah menyebabkan eksploitasi lahan yang berlebihan, sehingga muncul penurunan daya dukung lahan yang akan menurunkan kapasitas lahan dalam mendukung keberlanjutan pertanian (Moniaga, 2011; Hariyanto, 2018).

Ketidakseimbangan atau penurunan daya dukung lahan pertanian menurut Talumingan \& Jocom (2017); Herlindawati (2018) dipengaruhi oleh jumlah penduduk yang terus meningkat, peningkatan infrastruktur sosal ekonomi, konversi lahan pertanian, industrialisasi, meningkatnya persentase sejumlah petani dan penurunan luas lahan yang tersedia. 
Padahal, daya dukung lahan menjadi salah satu aspek yang terpenting dalam menunjang pertanian berkelanjutan. Hal ini terjadi karena kegiatan pertanian yang berkelanjutan tidak terlepas dari ketersediaan lahan pertanian, baik secara kualitas maupun secara kuantitas. Oleh karena itu, agar ketersediana lahan pertanian di masa depan dapat diprediksi maka mengkaji secara mendalam tingkat daya lahan pertanian di suatu wilayah menjadi sangat penting (Muta'ali, 2015).

Menurunnya daya dukung lahan pertanian dan keberlanjutan pertanian, juga tidak terlepas dari pengaruhan perubahan sistem sosialbudaya yang ada dalam lingkungan masyarakat petani. Salah satu aspek sosial-budaya yang cukup berperan dalam mempengaruhi perubahan daya dukung dan kebarlanjutan lahan pertanian adalah sistem pembagian lahan secara turun temurun. Pembagian lahan tersebut telah menyebabkan pemilikan lahan petani semakin sempit (Sudrajat, 2013; Sudrajat, 2015). Akibatnya, daya dukung lahan pertanian yang dapat menopong kehidupan petani di masa yang akan datang akan sangat mengkhawatirkan. Hal ini terjadi karena petani tidak merasa cukup untuk tetap bertahan dengan lahan pertaniannya sehingga keberlanjutan pertanian tidak bisa dipertahankan (Sudrajat $2013 \&$ Muta'ali 2015).

Penyebab lain menurunnya daya dukung lahan adalah hilangnya sistem nilai socio-culture tradisional petani yang berbasis alamiah yaitu; semakin melemahnya sejumlah pranata sosial yang dipraktekan dalam kegiatan pertanian. Melemahnya pranata sosial dalam lingkungan masyarakat petani ditandai dengan menurunnya kualitas lingkungan sosial, hilangnya sistem gotong royong serta pada taraf-taraf tertentu berubahnya nilai-nilai kearifan lokal dan norma yang berlaku dalam kehidupannya (Suhartini, 2009; Ridwan 2007; Sunarya dkk. 2016; Isman to dkk. 2012; Sudrajat 2018: Prayoga dkk. 2019).

Perubahan nilai socio-culture yang salah satunya dicirikan dengan hilangnya nilai kearifan lokal merupakan salah satu dampak negatif dari adanya revolusi hijau. Revolusi hijau yang ditandai dengan perkembangan teknologi pertanian menuntut adanya ektensifikasi dan intensifikasi pertanian. Bahkan, revolusi hijau juga telah menghancurkan sistem socio-culture tradisional dan pengetahuan tradisional petani yang selama bertahun-tahun berjalan selaras dengan daya dukung lingkungan (Zamroni 2010 \& Sukayat 2013). Dampak revolusi hijau, juga tidak hanya merubah nilai socioculture petani, namun juga telah merusak sumber daya lingkungan dan menciptakan ketergantungan petani pada input bahan kimia (Prayoga dkk. 2019 \& Sudrajat 2018).

Daya dukung lahan pertanian merupakan kemampuan lahan pertanian untuk mendukung kehidupan petani dalam melakukan aktivitas pertanan. Daya dukung lahan pertanian pada dasarnya sangat bergantung pada persentase lahan yang dapat digunakan untuk kegiatan pertanian, besarnya hasil pertanian persatuan luas dan fekuensi panen (Soemarwoto 1983 \& Hariyanto dkk. 2018). Sementara itu, Manik (2003) daya dukung lahan pertanian adalah suatu ukuran jumlah individu dari suatu populasi yang dapat didukung oleh lahan pertanian yang dapat memenuhi kebutuhan hidupnya. Oleh karena itu, daya dukung lahan pertanian sangat ditentukan oleh potensi sumber daya lahan yang tersedia dan teknologi serta jenis pekerjaan dan pendapatan penduduk. Berdasarkan hal tersebut maka ketersediaan lahan pertanian yang dapat dikelola dan dimanfaatkan untuk pertanian akan memberikan daya dukung yang lebih baik dan akan terjadi sebaliknya.

Menurut Pusat Stusi Sumberdaya Lahan (2013) secara umum ada dua faktor yang mempengaruhinya perbedaan daya dukung lahan pertanian yaitu; faktor internal dan ekternal. Faktor internal meliputi kondisi sosial ekonomi penduduknya dan kondisi fisik yang meliputi topografi yaitu kemiringan lereng dan elevasi (titik ketinggian) lahan; parameter iklim yaitu curah hujan dan temperatur; dan unsurunsur tanah seperti; drainase tanah, tekstur bahan kasar, kedalaman tanah, ketebalan gambut, alkalinitas, bahaya erosi, bahaya banjir atau genangan, dan keasaman tanah. Faktor faktor ekternalitas yaitu situasi geostrategi, geopolitik, dan geokkonomi. Sementara itu, menurut Riyadi dan Bratakusumah (2004) paling tidak ada lima faktor yang mempengaruhi daya dukung lahan pertanian yaitu; total luas lahan pertanian ada dalam suatu wilayah, frekuensi panen, jumlah rumahtangga tani yang tergantung pada sumber daya lahan, persentase jumlah penduduk yang yang berkerja di pertanian, dan ukuran rata-rata lahan pertanian yang dimiliki petani. Apabila faktor-faktor tersebut tidak lagi mendukung terhadap kegiatan pertanian maka tidak menutup kemungkinan daya dukung lahan pertanian akan semakin rendah dan pada akhirnya keberlanjutan pertanian tidak bisa dipertahankan.

Keberlanjutan pertanian merupakan implementasi dari pembangunan berkelanjutan. Oleh karena itu, menurut Shepherd (1998) keberlanjutan pertanian memberikan makna bahwa pertanian dapat dilakukan secara berkelanjutan sampai batas waktu yang tidak ditentukan. Berdasarkan hal tersebut maka keberkelanjutan pertanian harus memperhatikan beberapa prinsip yaitu: pertama menggunakan sistem input luar yang efektif; produktif, murah, dan membuang metode produksi yang menggunakan sistem input dari industri; kedua memahami dan menghargai kearifan lokal serta lebih banyak melibatkan peran petani dalam pengelolaan sumberdaya alam dan pertanian; dan ketiga melaksanakan konservasi sumberdaya alam yang digunakan dalam sistem produksi. Jika semua prinsip ini dapat direalisasi dalam kehidupan petani maka keberlanjutan pertanian akan dapat dipertahankan dengan baik dan akan terjadi sebaliknya.

Menurut Untung (1989) keberlanjutan pertanian 
dicirikan oleh beberapa aspek diantaranya adalah; pertama mampu meningkatkan produksi pertanian dan menjamin keamanan pangan di dalam negeri; kedua mampu menghasilkan pangan yang terbeli dengan kualitas nutrisi yang tinggi serta meminimalkan kandungan bahanखbahan pencemar kimia dan organisme yang memba-hayakan; ketiga tidak mengurangi dan merusak kesuburan tanah, tidak meningkatkan erosi, dan meminimalkan ketergantungan pada sumber daya alam tidak terbarukan; keempat mampu mendukung kehidupan masyarakat pedesaan dengan meningkatkan kesempatan kerja, menyediakan penghidupan yang layak dan mantap bagi para petani; kelima tidak membahayakan kesehatan masyarakat yang bekerja atau hidup di lahan pertanian dan yang mengkonsumsikan hasil pertanian; dan keanam melestarikan dan meningkatkan kualitas lingkungan hidup di lahan pertanian dan perdesaan serta melestarikan sumber daya alam dan keanekaragaman hayati setempat.

Pertanian berkelanjutan menurut Gliessman at al., (2010) \& Husodo, (2005) dicirikan oleh beberapa kriteria yaitu; (1) layak secara ekonomi; (2) layak secara ekologis dan bersahabat; (3) layak secara sosial; (3) cocok secara budaya; dan (4) merupakan sistem dan pendekatan yang holistik. Hal ini sejalan dengan yang dikemukakan Sudrajat (2013) \& Sudrajat, (2015) bahwa lahan pertanian sawah yang masih potensial berkelanjutan dapat dilihat dari 5 (lima) pendekatan yaitu (1)Pendekatan ekonomi, secara ekonomi lahan sawah potensial berkelanjutan dicirikan degan nilai produktivitas per satuan luas lahan tinggi dengan biaya pengelolaan yang rendah. (2) Pendekatan sosial, secara sosial lahan sawah potensial adalah lahan sawah yang selalu terkait dengan nilai-nilai sosial yang diberikan lahan sawah pada pemiliknya. Ini berarti jika petani sebagai pemilik lahan masih memandang penting akan nilai sosial lahan tersebut maka tidak menutup kemungkinan petani akan selalu dekat dengan lahannya. (3) Pendekatan lingkungan, lahan sawah potensial berkelanjutan secara lingkungan selalu dikaitkan kondisi lingkungan fisik lahan sawah dalam mempengaruhi produktivitasnya. (4)Pendekatan Aksesibilitasnya, berdasarkan pendekatan aksesibilitas lahan sawah potensial berkelanjutan adalah lahan sawah yang dicirikan dengan aksesibilitas sangat rendah karena jika akses lahan sawah cukup baik maka potensi mengalami perubahan ke non pertanian akan lebih besar. (5)Pendekatan lingkungan tempat tinggal petani, pendekatan ini menitikberatkan pada homogenitas petani yang ada di lingkungan tempat tinggalnya. Jika di lingkungan tempat tinggal petani masih didominasi petani maka potensi keberlanjutan pertanian akan lebih besar dibandingkan dengan kondisi lingkungan dimana petaninya sudah menjadi bagian yang termarjinalkan.

Menurut Saida dkk. (2011) berkelanjutan usahatani holtikultura dapat dicirikan dari 4 (empat) dimensi yaitu; pertama dimensi ekologi yang terdiri dari lima atribut yaitu tingkat erosi yang terjadi, ketersediaan bahan organik, kualitas hasil tanaman hortikultura, produktivitas tanaman hortikultura, dan pengelolaan lahan. Kedua dimensi ekonomi yang terdiri dari enam atribut yaitu komoditas unggulan tanaman hortikultura, harga produk komoditas hortikultura, kontribusi terhadap pendapatan petani, pengelolaan hasil pertanian hortikultura, luas lahan garapan, dan ketersediaan pemasaran. Ketiga dimensi yang terdiri dari lima atribut yaitu intensitas penyuluhan dan pelatihan mengenai teknologi ramah lingkungan, adopsi teknologi konservasi tanah, eksistensi layanan pemerintah, pengetahuan masyarakat tentang lingkungan, persepsi masyarakat tentang partisipatori, dan persepsi masyarakat terhadap upaya konservasi tanah. Keempat dimensi kelembagaan yang terdiri dua atribut yaitu keberadaan kelompok tani dan intensitas pertemuan kelompok tani. Kelima dimensi teknologi yang terdiri dari lima atribut yaitu teknik penggunaan mulsa, penggunaan pupuk organik dan biofertilizer, teknologi pembuatan pupuk organik, intensitas penggunaan pestisida, dan teknologi pembuatan biopestisida. Hal yang sama dikemukakan Charles (2001) bahwa untuk mengkaji keberlanjutan kegiatan perikanan dapat dianalisis dari empat aspek keberlanjutan, yakni keberlanjutan ekologi (ecological sustainability), keberlanjutan sosio-ekonomi (socio-economic stistainability), keberlanjutan komunitas (community sustainability) dan keberlanjutan kelembagaan (institutional sustainability).

Sementara itu, Sutanto (2006) keberlanjutan pertanian dicirikan oleh beberapa aspek yaitu: (1) mantap secara ekologis yang berarti mampu mempertahankan kualitas sumber daya alam dan kemampuan agroekosistem secara keseluruhan; (2) bisa berlanjut secara ekonomis yang berarti dapat mengembalikan biaya dan tenaga yang dikeluarkan serta meningkatkan penghasilan;(3) adil yang berarti adil terhadap manusia dan lingkungan; (4) manusiawi yang berarti menghargai semua bentuk kehidupan; dan (5) luwes artinya para petani mampu menyesuaikan diri dengan perubahan kondisi usaha tani yang berlangsung terus.

Keberlanjutan pertanian menurut Harington (1992) dapat ditinjau dari berbagai aspek dan harus disadari bahwa aspek-aspek tersebut bersifat dinamis sesuai dengan perkembangan teknologi dan sosial ekonomi masyarakat. Adapun aspek yang dimaksudkan tersebut adalah aspek etika dan tanggungjawab moral dan aspek agroekologi. Sementara itu, keberlanjutan pertanian dan daya dukung lahan menurut Riyadi dan Bratakusumah (2004) tidak terlepas dari masalah internal yaitu: sejumlah masalah terkait dengan semakin kecilnya area lahan, topografi bergunung dan bergelombang, jenis tanah, kesuburan dan nutrisi lahan yang terbatas, sedangkan masalah ekternal yaitu masalah yang datang dari luar lahan seperti: kondisi alam bisa terkait dengan masalah pencemaran lingkungan, bencana alam (gempa, banjir dan lonsor) dan pengaruh iklim (badai, 
kekeringan dan banjir).

Hal yang sama dikemukan Notohadiprawiro (1991); Supardi, (1994); Suryanto (2007) \& Soemarwoto (2001) bahwa daya dukung lahan pertanian dan berkelanjutan pertanian ditentukan oleh banyak faktor yaitu faktor biofisik dan sosial-budaya. Faktor biofisik yang sangat penting dalam menentukan daya dukung dan berkelanjutan pertanian yaitu proses ekologi yang merupakan sistem pendukung kehidupan dan keanekaragaman jenis hayati yang merupakan sumberdaya genetik, faktor geografi (iklim, perubahan cuaca, kesuburan tanah, erosi). Sementara itu, faktor sosial-budaya yang sangat penting dalam menentukan dalam daya dukung lahan dan berkelanjutan pertanian yaitu terkait kemiskinan, kemilikan sumberdaya atau kekayaan, pengetahuan dan pendidikan, tradisi dan budaya, rasionalitas petani, kearifan lokal dan aspek sosial budaya lainnya.

Perubahan daya dukung dan keberlanjutan pertanian menurut Padjarajani (2008) \& Moniaga (2011) terjadi pada daerah yang dinamika kepadatan penduduk tinggi, pemilikan lahan pertanian sempit, mengalami transformasi kegiatan dari pertanian ke non pertanian, mobilitas penduduk yang tinggi, interaksi aktivitas perdesaan dan perkotaan yang tinggi, serta terjadi percampuran penggunaan lahan yang intensif antara permukiman dan aktivitas ekonomi lainnya. Jika fenomen tersebut terus berlanjut maka daya dukung dan keberlanjutan pertanian di daerah tersebut tidak akan dapat dipertahankan lagi.

Ini berarti mengandung makna bahwa daya dukung lahan pertanian merupakan salah satu komponen penting dalam menentukan keberlanjutan pertanian. Hal ini terjadi karena tanpa adanya dukungan lahan pertanian maka keberlanjutan pertanian tidak akan dapat dipertahankan. Berdasarkan hal tersebut maka penelitian ini dilakukan dengan tujuan untuk mengkaji daya dukung lahan pertanian dan keberlanjutan pertanian di Desa Duren Kecamatan Bandungan Semarang.

\section{METODE PENELITIAN}

Penelitian ini dilakukan di Desa Duren Kecamatan Bandungan Kabupaten Semarang. Data yang dikumpulkan terdiri dari data primer dan data sekunder. Populasi dalam penelitian ini adalah petani yang tinggal di lokasi penelitian dan aktif melakukan kegiatan usahatani. Jumlah sampel diambil sebanyak 92 rumahtangga tani yang diambil secara proposional dari setiap dusun, sedangkan pengambil sampel di lapangan secara random sampling.

Variabel penelitian yang dianalisis terdiri dari: (1) karakteristik sosial-ekonomi rumahtangga tani; (2) aspek keberlanjutan pertanian yang dilihat dari dimensi sosial, dimensi ekonomi, dimensi lingkungan, dimensi kelembagaan dan dimensi teknologi; (3) daya dukung lingkungan; dan (4) persepsi petani terhadap daya dukung lahan pertanian. Pengukuran variabel yang bersifat kualitatif dilakukan dengan metode skala likerta, sedangkan pengukuran variabel lainnya disesuaikan dengan jenis datanya. Pengukuran variabel daya dukung lahan dilakukan dengan menggunakan persamaan berikut:

$$
\text { A X r }
$$

$\mathrm{CCR}=$

$$
\mathrm{H} \times \mathrm{h} \times \mathrm{F}
$$

dimana:

$\mathrm{CCR}=$ kemampuan daya dukung lahan pertanian

$\mathrm{A}=$ Jumlah total area yang dapat digunakan untuk kegiatan pertanian

$\mathbf{r}=$ Frekuensi panen per hektar per tahun

$\mathrm{h}=$ Jumlah KK (rumahtangga tani)

$\mathrm{H}=$ Persentase $\mathrm{KK}$ hidup disektor pertanian

$\mathrm{F}=$ Ukuran lahan pertanian rata-rata yang dimiliki petani Adapun asumsi yang digunakan sebagai interpretasi hasil perhitungan analisis daya dukung lahan pertanian adalah sebagai berikut:

Jika $\mathrm{CCR}>1$

Artinya berdasarkan kuantitas lahannya, masih memiliki kemampuan untuk mendukung kebutuhan pokok manusia dan masih mampu menerima tambahan penduduk. Pembangunan di wilayah tersebut masih dimungkinkan bersifat ekspansif dan eksploratif lahan.

Jika CCR $<1$

Artinya berdasarkan jumlah lahan yang ada, maka di wilayah tersebut sudah tidak mungkin lagi dilakukan pembangunan yang bersifat ekspansif dan eksploratif lahan. Lahan-lahan yang berada pada posisi demikian perlu mendapatkan program peningkatan produktivitas, intensifikasi dan ekstensifikasi melalui perbaikan teknologi atau menekan pertumbuhan penduduk.

Jika $\mathrm{CCR}=1$

Artinya berdasarkan jumlah lahan, daerah ini masih memiliki keseimbangan antara kemampuan lahan dan jumlah penduduk, namun demikian kondisi ini perlu diwaspadai karena jika pertambahan penduduk tidak terkendali akibat pembangunan yang sangat cepat akan dapat menyebabkan menurunnya kemampuan daya dukung.

Sementara itu, pengukuran variabel keberlanjutan pertanian dilakukan melalui beberapa tahapan, yaitu: (1) tahap penentuan atribut atau kriteria berkelanjutan pertanian yang mencakup lima dimensi (sosial, ekonomi, lingkungan, kelembagaan dan teknologi), (2) tahap penilaian dari setiap atribut dalam skala ordinal berdasarkan kriteria keberlanjutan setiap dimensi, (3) tahap analisis ordinasi yaitu dengan memberikan nilai skor dari setiap dimensi.

Pengukuran data dilakukan dengan skala likerts dan dianalisis dengan menggunakan metode kuartil (Q). Pada perhitungan metode kuartil akan diperoleh nilai batas bawah (B), nilai batas atas (A), nilai Q1, nilai Q2, nilai Q3 dan nilai hasil survey lapangan. Untuk mengetahui arah kecederungan dari keberlanjutan pertanian maka nilai hasil survey dicocok 
dengan nilai Q1, Q2 dan Q3 yang telah dikelompokan menjadi 4 (empat) kelompok yaitu:

Batas bawah $\mathrm{s} / \mathrm{d} \mathrm{Q} 1=$ keberlanjutan pertanian sangat rendah

$>\mathrm{Q} 1 \mathrm{~s} / \mathrm{d}<\mathrm{Q} 2 \quad=$ Keberlanjutan pertanian rendah

$>$ Q2 $s / d<Q 3=$ Keberlanjutan pertanian tinggi

$>$ Q3 $\mathrm{s} /$ d batas atas $=$ Keberlanjutan pertanian sangat tinggi

\section{HASIL PENELITIAN DAN PEMBAHASAN}

\section{Deskripsi Daerah Penelitian}

Desa Duren terletak kurang lebih $0,5 \mathrm{Km}$ dari Ibukota Kecamatan Bandungan dan $16 \mathrm{Km}$ dari Ibukota Kabupaten Semarang. Luas wilayah Desa Duren seluas 308 hektar, terdiri lahan pertanian pertanian seluas 191,32 hektar yang terdiri dari lahan sawah seluas 136 hektar, lahan non sawah seluas 55,32 hektar dan lahan non pertanian seluas 116,68 hektar. Desa Duren memiliki topografi yang berbukit dengan ketinggian kurang lebih 834 meter diatas permukaan laut (dpl) dan memiliki rata-rata temperatur udara tertinggi $22,64^{\circ} \mathrm{C}$ dan terendah $13,91^{\circ} \mathrm{C}$ (BPS 2018). Kondisi topografi tersebut akan berpengaruh terhadap aktvitas pertanian dan perkembangan non pertaniannya di wilayah Desa Duren.

Secara administrasi Desa Duren sebelah utara berbatasan dengan Desa Jubelan, sebelah timur berbatasan dengan Desa Jimbaran dan Desa Sidomukti, sebelah barat berbatasan dengan Desa Bandungan dan Desa Kentengan, sedangkan sebelah selatan berbatasan dengan Desa Jetis dan Desa Milir (Gambar 1). Jumlah penduduk Desa Duren pada tahun 2018 sebanyak 5.954 jiwa atau sekitas 10,28\% dari total jumlah penduduk Kecamatan Bandungan, sedangkan kepadatan penduduknya mencapai 1.933 jiwa $/ \mathrm{km}^{2}$.

Pekerjaan penduduk Desa Duren sebanyak $28,42 \%$ bergerak di bidang pertanian yang terdiri dari sebanyak 1.158 petani, sebanyak 47 buruh tani dan sebanyak 1 orang sebagai peternak, sedangkan penduduk yang bekerja di non pertanian jumlahnya lebih banyak yaitu mencapai $71,58 \%$ bergerak bidangan jasa, industri dan perdagangan (BPS, 2018 \& Monografi Desa 2018).

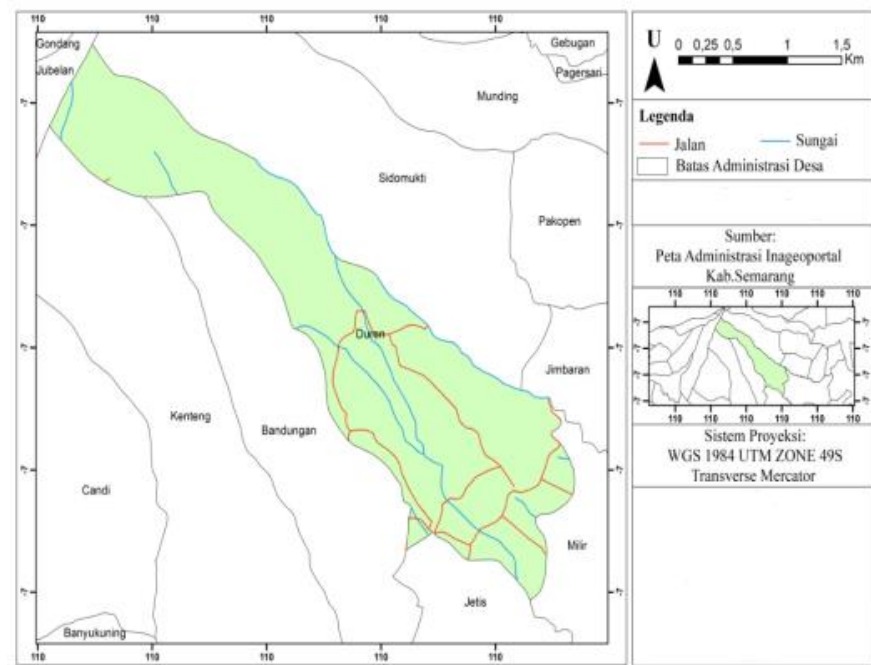

Gambar 1. Peta Administrasi Desa Duren Kecamatan Bandungan Kabupaten Semarang
Karakteristik Demografi dan Sosial-Ekonomi Petani Desa Duren

Salah satu aspek demografi yang cukup menarik dianalisis adalah faktor umur. Hal ini terjadi karena faktor umur sangat berkaitan erat dengan usia produktif dan non produktif. Hasil penelitian pada Tabel 1 menemukan rata-rata umur petani di Desa Duren masih produktif yaitu berumur 52,7 tahun. Namun dilihat dari pendidikanya sebagian besar masih berpendidikan SD dan tidak tamat SD. Dilihat dari rata-rata jumlah anggota rumahtangganya hanya sebanyak 4 orang, dengan rata-rata yang bekerja di pertanian sebanyak 2 orang. Sementara itu, dilihat dari penguasaan lahan pertanian oleh rumahtangga tani rata-rata hanya seluas 0,1184 hektar, sehingga secara ekonomi kurang efisien jika dilakukan upaya intensifikasi pertanian berbasis teknologi.

\section{Daya Dukung Lahan Pertanian Desa Duren}

Lahan merupakan salah satu aspek yang penting dalam mendukung keberlangsungan hidup petani. Petani membutuhkan lahan untuk kegiatan pertanian (perkebunan, perikanan, peternakan dan penggunaan non pertanian). Berdasarkan hal tersebut maka kemampuan daya dukung lahan pertanian menjadi sangat penting untuk diketahui agar lahan pertanian dapat dimanfaatkan secara berkelanjutan. Analisis daya dukung lahan akan berkaitan erat dengan pembangunan pertanian berkelanjutan, karena dengan mengetahui daya dukung lahan berarti dapat diprediksi kemampuan lahan pertanian di masa depan. Hasil perhitungan daya dukung lahan pertanian diperoleh nilai CCR sebasar 0,1372 . Jika nilai $\mathrm{CCR}<1$ memberi arti bahwa daya dukung lahan pertainan dalam mendukung kehidupan petani di Desa Duren sudah tidak mungkin lagi dilakukan pembangunan pertanian yang bersifat ekspansif dan eksploratif lahan. Walaupun demikian, agar lahan pertanian tersebut tetap menopong kehidupan petani, maka upaya peningkatan produktivitas, intensifikasi dan efisiensi melalui perbaikan teknologi harus terus diupayakan.

Rendahnya daya dukung lahan pertanian di Desa Duren diperkuat dari hasil pengukuran kualitatif yang dianalisis dengan metode kuartir (Q). Hasil analisis diperoleh nilai batas bawah (B) sebesar 552, nilai batas atas (A) sebesar 2.760 , nilai Q1 sebesar 1.104, nilai Q2 sebesar 1.656, nilai Q3 sebesar 2.208 dan nilai hasil survey yang diperoleh dari responden sebesar 1.527 (Gambar 2).

Keterangan:

$\mathrm{B}$ s/dQ1 = Persepsi petani terhadapa daya dukung lahan sangat rendah

$>$ Q1 $/$ d $<$ Q2 = Persepsi petani terhadapa daya dukung lahan rendah

$>$ Q2 $/ \mathrm{d}<\mathrm{Q} 3=$ Persepsi petani terhadapa daya dukung lahan tinggi

$>$ Q3 = Persepsi petani terhadapa daya dukung lahan sangat tinggi 
Tabel 1. Karakteristik Demografi dan SosialEkonomi Petani Desa Duren Kecamatan Bandungan

\begin{tabular}{lcc}
\hline Kelompok Umur & Frekuensi (f) & Persentase (\%) \\
\hline$<41$ tahun & 14 & 15,2 \\
$41-64$ tahun & 63 & 68,5 \\
65 tahun & 15 & 16,3 \\
Total & 92 & 100,0 \\
Rata-rata & \multicolumn{2}{c}{52,7 tahun } \\
\hline Pendidikan & Frekuensi (f) & Persentase (\%) \\
\hline Tidak tamat SD & 37 & 40,2 \\
Tamat SD & 44 & 47,8 \\
Tamat SLTP & 6 & 6,5 \\
Tamat SLTP & 5 & 5,4 \\
Total & 92 & 100,0 \\
\hline
\end{tabular}

\begin{tabular}{lcc}
\hline $\begin{array}{l}\text { Jumlah Anggota } \\
\text { Rumahtangga }\end{array}$ & Frekuensi (f) & Persentase (\%) \\
\hline$<3$ orang & 9 & 9,8 \\
$3-5$ orang & 71 & 77,2 \\
$>5$ orang & 12 & 13,0 \\
Total & 92 & 100,0 \\
$\quad$ Rata-rata & & 4
\end{tabular}

\begin{tabular}{lcc}
\hline $\begin{array}{l}\text { Anggota Ru- } \\
\text { mahtangga Yang } \\
\text { Bekerja Di Pertanian }\end{array}$ & Frekuensi (f) & Persentase (\%) \\
\hline 1 orang & 29 & 31,5 \\
2 orang & 59 & 64,1 \\
3 orang & 4 & 4,3 \\
Total & 92 & 100,0 \\
Rata-rata & \multicolumn{2}{c}{} \\
\hline Luas penguasaan & Frekuensi & Persentase \\
Lahan Pertanian & 78 & 84.8 \\
\hline$<0,25$ ha & 10 & 10.9 \\
$0,25-0,5$ ha & 4 & 4.3 \\
$\geq 0,5$ ha & 92 & 100.0 \\
Total & &
\end{tabular}

Sumber: Data Primer, 2019

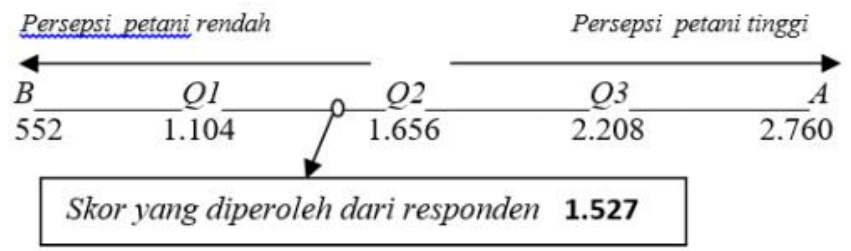

Gambar 2. Persepsi Petani Terhadap Daya Dukung Lahan Pertanian

Hasil perhitungan tersebut menunjukkan bahwa nilai hasil survey lapangan berada di antara Q1 dan Q2. Ini berarti arah kecendarungan persepsi petani terhadap daya dukung lahan pertanian di Desa Duren menuju kearah yang rendah. Gejala rendahnya persepsi petani terhadap daya dukung lahan pertanian disebabkan karena beberapa hal diantaranya adalah; (1) petani merasakan luas lahan yang dikuasai petani dianggap sudah tidak layak karena rata penguasaannya hanya seluas 0,1184 hektar; (2) petani merasakan persentase jumlah petani dan buruh tani sudah tidak seimbang dengan luas lahan pertanian tersedia; (3) petani merasakan pendapatan hasil usahatani lebih rendah dibandingkan dengan yang diterima dari non pertanian, (4) petani merasakan ketersedian lahan non pertanian tidak cukup luas, (5) petani merasakan jumlah penduduk terus mengalami pertambahan; dan (6) petani merasakan perbandingan ketersedian luas lahan pertanian dengan non pertanian semakin kecil. Rendahnya persepsi petani terhadap daya dukung lahan pertanian sejalan dengan yang dikemukan Riyadi dan Bratakusumah (2004) bahwa petani akan menilai rendah terhadap daya dukung lahan jika total area lahan pertanian terus berkurang, frekuensi panen yang pendek, jumlah kepala rumahtangga tani yang terus meningkat, persentasase jumlah penduduk bertambah dan ukuran luas rata-rata luas lahan yang dikuasai petani relatif sempit. Berdasarkan tersebut tersebut maka cukup logis jika petani di Desa Duren secara umum memiliki persepsi rendah terhadap daya dukung lahan pertaniannya.

Keberlanjutan Pertanian di Desa Duren

Keberlanjutan pertanian di Desa Duren tidak terlepas dari pengaruh kondisi fisik maupun sosial ekonomi masyarakatnya. Hal ini terjadi karena jika aspek fisik maupun aspek sosial ekonomi tidak lagi mendukung terhadap kegiatan pertanian, maka tidak menutup kemungkinan aktivitas pertanian tidak dapat berkelanjutan (Suryanto, 2007 \& Soemarwoto, 2001). Berdasarkan hal tersebut maka keberlanjutan pertanian harus dianalisis dari berbagai dimensi, sehingga dapat dilihat arah kecenderungan dari setiap dimensi dalam mendukung keberlanjutan pertanian. Oleh karena itu, pada penelitian ini keberlanjutan pertanian dianalisis dari 5 (lima) dimensi yaitu; dimensi sosial, dimensi ekonomi, dimensi lingkungan, dimensi kelembagaan dan dimensi teknologi. Pengukuran keberlanjutan pertanian dari 5 (lima) dimensi menggunakan skala likerts dan dianalisis dengan metode kuartil (Q). Hasil analisis diperoleh nilai batas bawah (B) sebesar 3.404, nilai batas atas (A) sebesar 17.020, nilai Q1 sebesar 6.808 , nilai Q2 sebesar 10.212, nilai Q3 sebesar 13.616 dan nilai hasil survey yang diperoleh dari responden sebesar 11.077 (Gambar 4).

Keterangan:

$\mathrm{B} \mathrm{s} / \mathrm{d} \mathrm{Q1}=$ Keberlanjutan pertanian sangat rendah

$>\mathrm{Q} 1 \mathrm{~s} / \mathrm{d}<\mathrm{Q} 2=$ Keberlanjutan pertanian rendah

$>$ Q2 $s / d<Q 3=$ Keberlanjutan pertanian tinggi

$>$ Q3 $=$ Keberlanjutan pertanian sangat tinggi 


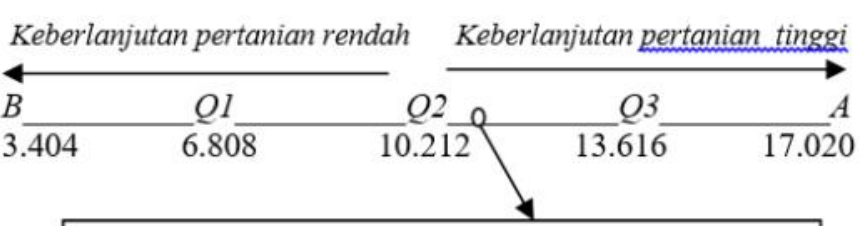

Skor yang diperoleh dari responden 11.077

\section{Gambar 3. Keberlanjutan Pertanian}

Hasil perhitungan menunjukkan nilai hasil survey lapangan berada di antara Q1 dan Q2. Ini berarti keberlanjutan pertanian dari hasil analisis 5 (lima) dimensi masih tergolong tinggi. Dengan demikian, maka hasil penelitian ini sejalan yang diungkapkan Rivai (2011) bahwa keberlajutan pertanian paling tidak harus didukung tiga dimensi yaitu; dimensi ekonomi (profit), dimensi sosial manusia (people), dan dimensi ekologi alam (environment). Berdasarkan hal tersebut maka cukup logis jika keberlanjutan pertanian di Desa Duren secara keseluruhan masih di golongkan tinggi. Hal ini terjadi karena dari 5 (lima) dimensi, hanya 1 (satu) dimensi yang tergolong rendah yaitu dimensi sosial, sedangkan dari sisi dimensi ekonomi, dimensi lingkungan, dimensi kelembagan dan dimensi teknologi tergolong tinggi dalam mendukung keberlanjutan pertanian.Walaupun demikian, keberlanjutan pertanian di Desa Duren perlu diwaspadai karena nilai total skor hasil survey lapangan dari kelima dimensi tersebut tidak jauh dari nilai batas Q2. Hal ini terjadi karena jika ada perubahan dari kelima dimensi tersebut kearah negatif, maka nilai keberlanjutan menjadi turun sehingga akan menuju kearah keberlanjutan pertanian yang rendah. Untuk melihat arah kecenderungan dari setiap dimensi keberlanjutan tersebut maka dilakukan analisis secara mendalam dari setiap dimensi.

\section{Keberlanjutan pertanian berdasarkan dimensi sosial}

Keberlanjutan pertanian tidak terlepas dari niai-nlai sosial petani yang telah tumbuh dan berkembang secera turun temurun di dalam kehidupan masyarakatnya. Pada masa lalu nilai-nilai sosial tersebut telah berperan menentukan aktivitas pertanian dengan prinsip berwawasan lingkungan (Sudrajat, 2016). Namun dewasa ini, nilai sosial petani tersebut semakin memudar yang dicirikan dengan melemahnya sistem gotong royong, serta pada taraf-taraf tertentu berubahnya nilai-nilai kearifan lokal dan norma yang berlaku dalam kehidupannya (Suhartini, 2009; Sunarya dkk. 2016; Isman to dkk. 2012; Sudrajat 2018: Prayoga dkk. 2019).

Keberlanjutan pertanian dari dimensi sosial pada penelitian ini dianalisis dari persepsi petani terhadap 7 (tujuh) atribut nilai sosial petani yang terkait dengan kegiatan pertanian diantaranya adalah; (1) persepsi petani terhadap penerus petani dimasa yang akan datang (regenerasi petani), (2) persepsi petani terhadap lahan pertanian sebagai penghasil bahan pangan, (3) persepsi petani terhadap petani yang mampu mewariskan lahan pertanian pada keturunannya akan lebih terhormat, (4) persepsi petani terhadap nilai sosial lahan pertanian sebagai simbol kekayaan rumahtangga petani, (5) persepsi petani terhadap petani yang menjual lahan pertanian sebagai perbuatan yang tabu dan memalukan, (6) persepsi petani terhadap petani yang mampu mempekerjakan saudara, tetangga atau petani lain pada lahan pertaniannya dan (7) persepsi petani terhadap petani yang mampu mempertahankan lahan warisan sebagai wujud menjalankan amat atau wasiat leluhurnya.

Ketujuh inidikator keberlanjutan dari sisi dimensi sosial tersebut diukur dengan menggunakan skala likerts dan dianalisis dengan metode kuartil (Q). Hasil pengukuran dari dimensi sosial diperoleh nilai batas bawah (B) sebesar 644, nilai batas atas (A) sebesar 3.220, nilai Q1 sebesar $1.288, Q 2$ sebesar 1.932, nilai Q3 sebesar 2.576 dan nilai hasil survey yang diperoleh dari responden sebesar 3.220 (Gambar 4).

Keterangan:

B s/d Q1 = Keberlanjutan dari dimensi sosial sangat rendah

$>$ Q1 s $/ \mathrm{d}<\mathrm{Q} 2$ = Keberlanjutan dari dimensi sosial rendah

$>$ Q2 $\mathrm{s} / \mathrm{d}<\mathrm{Q} 3=$ Keberlanjutan dari dimensi sosial tinggi

$>$ Q3 s/d batas atas = Keberlanjutan dari dimensi sosial sangat tinggi

Keberlanjutan Pertanian

Keberlanjutan tinggi

\begin{tabular}{|c|c|c|c|c|}
\hline$B$ & $Q 1$ & $Q 2$ & $Q 3$ & $A$ \\
\hline 644 & 1.288 & 1.932 & 2.576 & 3.220 \\
\hline
\end{tabular}

Gambar 4. Keberlanjutan Pertanian Berdasarkan Dimensi Sosial

Hasil perhitungan menunjukkan nilai hasil survey lapangan berada di antara Q1 dan Q2. Ini berarti keberlanjutan pertanian di Desa Duren dari dimensi sosial tergolong rendah (Gambar 4). Rendahnya keberlanjutan pertanian dari dimensi sosial menunjukkan bahwa nilai sosial yang terkait dengan kegiatan pertanian tidak lagi dipraktekan dalam kehidupan petani. Hal ini terjadi karena ada beberapa alasan diantaranya adalah: (1) banyak petani yang tidak lagi menginginkan anaknya sebagai penerus petani dimasa yang akan datang, karena petani lebih menginginkan anak-anak sukses di non pertanian; (2) dari sisi status sosial petani tidak lagi merasa bangga hidup sebagai petani yang mampu menghasilkan bahan pangan; (3) dari sisi pemilikan lahan, petani tidak lagi menganggap bahwa lahan pertanian sebagai simbol kekayaan rumahtangga tani; dan (4) dari sosial kemasyarakatan; (a). petani tidak lagi mendapat penghormatan ketika mampu mewariskan lahan pertanian pada keturunannya, (b). petani tidak lagi merasa tabu atau malu ketika 
menjual lahan pertanian, (c) petani tidak lagi mendapat penghormatan ketika mampu memperkerjakan saudara, tetangga atau petani lain pada lahan pertaniannya; dan (d) petani tidak lagi menganggap bahwa mempertahankan merupakan wujud menjalankan amat atau wasiat leluhurnya. Dengan demikian, cukup logis jika dari sisi dimensi sosial keberlanjutan pertanian di Desa Duren tergolong rendah.

Jika fenomena ini dibiarkan terus, maka tidak menutup kemungkinan petani di Desa Duren akan semakin lemah komitmennya untuk bertahan di pertanian. Hal ini terjadi karena nilai sosial lahan pertanian yang dulu mengikat petani sudah mulai pudar. Hasil penelitian ini sejalan dengan hasil penelitian sudrajat (2016) yang menemukan bahwa rendahnya pandangan petani terhadap nilai sosial lahan merupakan salah satu asek yang menyebabkan rendah komitmen petani mempertahankan lahan sawah di pinggiran Kota Yogyarakta. Berdasarkan hal ini maka peran pemerintah dalam meningkatkan produktivitas dan pendapatan petani sangat penting agar petani menjadi lebih bangga lagi hidup sebagai seorang petani yang sukses.

\section{Kerberlanjutan pertanian berdasarkan dimensi ekonomi}

Keberlanjutan pertanian tidak terlepas dari dimensi ekonomi, karena tujuan utama kegiatan pemanfaatan lahan pertanian adalah mendapatkan keuntungan ekonomi. Namun demikian, dalam mendapatkan keuntungan ekonomi petani sering dihadapkan dengan ketidakpastian yang bersifat alamiah maupun yang bersifat ekonomi maupun sosial. Oleh karena itu, beberapa aspek dimensi ekonomi ini akan sangat terkait variabel ketidakpastian yang bersifat ekonomi yang dapat menentukan keberlanjutan pertanian dimasa depan (Sudrajat, 2018).

Keberlanjutan pertanian dari dimensi ekonomi pada penelitian ini dianalisis dari persepsi petani terhadap 7 (tujuh) atribut ekonomi yang terkait dengan kegiatan pertanian diantaranya adalah; (1) persepsi petani terhadap kemudahan dalam menjual hasil produksi pertanian; (2) persepsi petani terhadap lahan pertanian untuk memenuhi kebutuhan hidup; (3) persepsi petani terhadap kemudahan mendapatkan fasilitas pinjaman/kredit untuk modal usahatani; (4) persepsi petani terhadap keuntungan lokasi karena berdekatan dengan lokasi wisata atau pasar; (5) persepsi petani terhadap kemudahan mendapatan saprodi (bibit, obat-obat, pupuk dan peralatan pertanian); (6) persepsi petani terhadap kenaikan hasil produksi pertanian; dan (7) persepsi petani terhadap kestabilan harga hasil produk pertanian. Pengukuran ketujuh inidkator dimensi ekonomi tersebut menggunakan metode skala likerts dan dianalisis dengan metode kuartil (Q). Hasil pengukuran dari dimensi ekonomi diperoleh nilai batas bawah (B) sebesar 644 , nilai batas atas (A) sebesar 3.220, nilai Q1 sebesar 1.288 , nilai Q2 sebesar 1.932 dan nilai Q3 sebesar 2.576, sedangkan nilai hasil survey lapangan yang diperoleh dari responden sebesar 2.404 (Gambar 5). Hasil perhitungan menunjukan nilai hasil survey lapangan berada di antara Q2 dan Q3. Ini berarti daya dukung lahan.

Keterangan:

B s/d Q1

$=$ Keberlanjutan dari dimensi ekonomi sangat rendah

$>$ Q1 $s / d<Q 2=$ Keberlanjutan dari dimensi ekonomir rendah

$>$ Q2 $\mathrm{s} / \mathrm{d}<\mathrm{Q} 3=$ Keberlanjutan dari Dimensi ekonomi tinggi

$>$ Q3 $\mathrm{s} / \mathrm{d}$ batas atas = Keberlanjutan dari Deimensi ekonomi sangat tinggi

Masih tingginya dukungan dimensi ekonomi terhadap keberlanjutan pertanian disebabkan karena dari 7 (tujuh) indikator, diantaranya 4 (empat) indikator menuju kearah

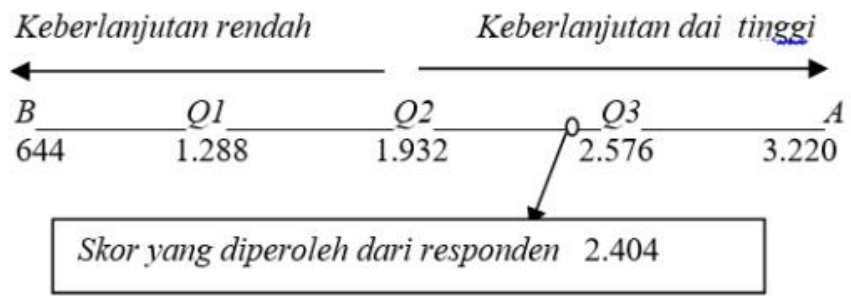

Gambar 5. berlanjutan Pertanian Berdasarkan Dimensi Ekonomi.

dimensi ekonomi yang tinggi, sedangkan 3 (tiga) indikator lainnnya menuju diarah dimensi ekonomi yang rendah. Adapun indikator dimensi ekonomi yang di persepsikan tinggi oleh petani dalam menunjang kegiatan pertanian diantaranya adalah terkait dengan kemudahan dalam menjual hasil produksi pertanian; kemudahan mendapatkan fasilitas pinjaman/kredit untuk modal usahatani keuntungan lokasi karena berdekatan dengan lokasi wisata atau pasar; dan kemudahan mendapatan saprodi (bibit, obat-obat, pupuk dan peralatan pertanian). Sementara itu, indikator dimensi ekonomi yang dipersepsikan oleh petani rendah dalam menunjang kegiatan pertanian diantaranya adalah lahan pertanian untuk memenuhi kebutuhan hidup; kenaikan hasil produksi pertanian; dan kestabilan harga hasil produk pertanian dipandang oleh petani sebagian besar petani kearah rendah dalam mendukung keberlanjuta pertanian. Berdasarkan hal tersebut maka, cukup logis jika dari dimensi ekonomi masih tinggi dalam mendukung keberlanjutan pertanian karena lebih dari separoh indikator dimensi ekonomi masih dinilai positif oleh para petani. Masih tingginya dukungan dimensi ekonomi terhadap keberlanjutan pertanian di lokasi penelitian sejalan dengan hasil hasil temuan Saida dkk. (2011) yang menemukan ahwa dimensi ekonomi masih cukup berperan dalam mendukung keberlanjutan usahatani holtikultura karena secara ekonimi hasil usahatani memberikan keuntungan ekonomi. 
Kerberlanjutan pertanian berdasarkan dimensi lingkungan

Aspek lingkungan merupakan salah satu aspek yang sangat penting dalam mempengaruhi keberlanjutan pertanian. Oleh karena itu, analisis dari sisi dimensi lingkungan terutama terkait dengan masalah lingkungan menjadi sangat penting untuk dianalisis secara mendalam. Keberlanjutan pertanian dari dimensi lingkungan pada penelitian ini dianalisis dari persepsi petani terhadap 11 (sebelas) atribut aspek lingkungan yang terkait dengan kegiatan pertanian diantaranya adalah; (1) persepsi petani terhadap kesuburan lahan sawah, (2) persepsi petani terhadap ketersediaan bahan-bahan pupuk alami dan obatobat organik, (3) persepsi petani terhadap ketaatan para petani dalam aturan penggunaan pupuk dan pestisida kimia, (4) persepsi petani terhadap kerawan potensi longsor lahan, (5) persepsi petani terhadap kerawan potensi erosi, (6) persepsi petani terhadap rintangan penyinaran matahari terhadap lahan pertanian, (7) persepsi petani terhadap jarak lokasi lahan pertanian dengan lahan terbangun atau kawasan binis, (8) persepsi petani terhadap potensi serangan hama dan penyakit tanaman, (9) persepsi petani terhadap kecocokan tanaman dengan temperatur udara, (1) persepsi petani terhadap kecukupan air untuk pertanian, dan (11) persepsi petani terhadap jarak lahan pertanian terhadap sumber pencemar lingkungan. Pengukuran indikator dimensi lingkungan menggunakan skala likerts dan kemudian dianalisis dengan metode kuartir (Q). Hasil pengukuran diperoleh nilai batas bawah (B) sebesar 3.036, nilai batas atas (A) sebesar 5.060, nilai Q 1 sebesar 2.024, nilai Q2 sebesar 3.036 dan nilai Q3 sebesar 4.048 , sedangkan nilai hasil survey lapangan yang diperoleh dari responden sebesar 3.867 (Gambar 6).

\section{Keterangan:}

Batas bawah s/d Q1 = Keberlanjutan dari dimensi lingkingan sangat rendah

$>\mathrm{Q} 1 \mathrm{~s} / \mathrm{d}<\mathrm{Q} 2 \quad=$ Keberlanjutan dari dimensi lingkingan rendah

$>$ Q2 $s / d<Q 3=$ Keberlanjutan dari dimensi lingkingan tinggi

$>$ Q3 $\mathrm{s} /$ d batas atas = Keberlanjutan dari dimensi lingkingan sangat tnggi

Hasil pengukuran seperti yang tampak pada Gambar 6 menunjukan bahwa dimensi lingkungan menunjukkan kearah yang positif atau kearah yang tinggi dalam mendukung keberlanjutan pertanian. Hal ini tampak dari

Keberlamiutan rendah

\begin{tabular}{|c|c|c|c|c|}
\hline B & $Q 1$ & $Q 2$ & Q3 & 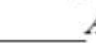 \\
\hline $1 . \overline{012}$ & 2.024 & 3.036 & $4.04 \overline{48}$ & 5.060 \\
\hline
\end{tabular}

Skor yang diperoleh dari responden 3.867

Gambar 6. Kerberlanjutan Pertanian Berdasarkan Dimensi Lingkungan. sisi kualitas lahan pertanian yang berkaitan dengan kesuburan lahan pertanian, petani menilai kearah positif karena dianggap masih subur sehingga produksinya masih tinggi. Petani juga memberikan penilaian kearah yang positif terhadap ketersediaan bahan pupuk organik dan obat-obat alami, karena petani masih merasa mudah mendapatkan bahan pupuk organik (pupuk kandang maupun pupuk kompos) dan obat-obatan alami untuk mencegah hama dan penyakit tanaman. Demikian juga, dalam aturan penggunaan pupuk dan obat kimia, petani masih memberikan nilai kearah yang positif karena petani selalu berpedoman pada aturan penggunaaannnya. Sementara itu, pada penilaian terhadap kerawan potensi longsor dan erosi petani menilai daerahnya, bukan merupakan daerah rawan lonsor maupun erosi karena datar. Berdasarkan kondisi ini maka cukup logis jika petani menilai lokasi lahan pertanian memiliki peluang yang rendah terjadinya longsor maupun erosi tanah.

Masih positifnya dimensi lingkungan dalam mendukung keberlanjutan pertanian juga terjadi karena petani mengangap tidak ada rintangan penyinaran matahari terhadap lahan pertaniannya. Hal yang sama juga, petani menganggap bahwa jarak lokasi lahan pertanian dengan kawasan terbangun atau kawasan binis (permukiman, industri, jasa, perdagangan dan lainnya) maupun terhadap sumber pencemar masih jauh, sehingga tidak menganggu terhadap kegiatan produksi pertanian. Demikian juga, dari sisi potensi serangan hama dan penyakit tanaman petani menilai kerah tidak ada potensi hama dan penyakit tanaman, dari sisi kecocokan tanaman dengan temperatur udara petani memberikan penilaian kearah yang cocok, dan terhadap kecukupan air untuk pertanian, petani memberikan menilai kearah ketersedian air yang cukup untuk kegiatan pertanan sepanjang tahun.

Hasil analisis tersebut memberikan gambaran bahwa atribut dimensi lingkungan masih memberikan dukungan yang tinggi terhadap keberlanjutan kegiatan pertanian di lokasi penelitian. Hasil temuan ini sejalan dengan hasil temuan Nurmalina (2008) \& Saida dkk. (2011) bahwa keberlanjutan pertanian sangat ditentukan oleh kondisi dimensi ekologi. Hal yang sama dikemukakan Wibowo dkk. (2001) bahwa keberlanjutan minapolitan sangat dipengaruh oleh kondisi ekologi yang terhindar dari tingginya laju alih fungsi lahan, kejadian kekeringan, rendahnya daya dukung pakan, terhindar dari peluang masuknya zat anorganik atau pencemar ke lingkungan budidaya dan ketersediaan lahan perikanan cukup.

Kerberlanjutan pertanian berdasarkan dimensi kelembagaan.

Aspek kelembagaan dalam berkelanjutan pertanian merupakan salah satu aspek utama yang menunjang terhadap kegiatan pertanian. Keberlanjutan pertanian berdasarkan dimensi kelembagaan dianalisis dari persepsi 
petani terhadap 6 (enam) atribut aspek kelembagaan yang terkait dengan kegiatan pertanian diantaranya adalah; (1) persepsi petani terhadap kecukupan jumlah penyuluh pertanian dalam melayani petani, (2) persepsi petani terhadap keanggotaan dan keaktifan petani dalam pertemuan kelompok tani, (3) persepsi petani terhadap peran kelembagaan kelompok tani dalam pembinaan petani, (4) persepsi petani terhadap ketersedian lembaga penyalur saprodi pertanian melalui koprasi/KUD, (5) persepsi petani terhadap ketersediaan lembaga pemasaran hasil produk pertanian melalui koprasi/KUD, dan (6) persepsi petani terhadap kemudahan mengakses modal usahatani dari lembaga keuangan mikro, melaui Koprasi simpan pinjam/ Bank. Pengukuran indikator dimensi kelembagaan tersebut menggunakan skala likerts dan dianalisis dengan metode kuartir (Q). Hasil pengukuran diperoleh nilai batas bawah (B) sebesar 552, nilai batas atas (A) sebesar 2.760, nilai Q 1 sebesar 1.104, nilai Q2 sebesar 1.652 dan nilai Q3 sebesar 2.208 , sedangkan nilai hasil survey lapangan yang diperoleh dari responden sebesar 1.731 (Gambar 7).

Keterangan:

Batas bawah s/d Q1 = Keberlanjutan pertanian dari dimensi kelembagaan sangat rendah

$>\mathrm{Q} 1 \mathrm{~s} / \mathrm{d}<\mathrm{Q} 2=$ Keberlanjutan pertanian dari dimensi kelembagaan rendah

$>$ Q2 $\mathrm{s} / \mathrm{d}<\mathrm{Q} 3=$ Keberlanjutan pertanian dimensi dari kelembagaan tinggi

$>$ Q3 s $/$ d batas atas = Keberlanjutan pertanian dari dimensi kelembagaan sangat tinggi

Hasil pengukuran seperti yang tampak pada Gambar 7 menunjukkan bahwa dari sisi dimensi kelembagaan mengarah kearah yang tinggi dalam mendukung keberlanjutan pertanian. Tingginya peran dimensi kelembagan dalam mendukung keberlanjutan pertanian terjadi karena semua aspek dimensi kelembagaan seperti; yang terkait dengan kecukupan jumlah penyuluh pertanian dalam melayani petani dinilai petani masih cukup jumlahnya, sehingga dapat melayani semua masyarakat tani dengan baik. Hal yang sama juga terlihat dalam keanggotaan dan keaktifan petani dalam pertemuan kelompok tani dinilai semua anggota relatif aktif dalam kelompok tani, dan peran kelembagaan kelompok tani dalam pembinaan petani juga dinilai masih berperan. Demikian juga, terkait dengan ketersedian lembaga penyalur (koprasi/KUD) saprodi per-

Keberlamjutan rendah

\begin{tabular}{|c|c|c|c|}
\hline B & $Q 1$ & $Q 2-Q$ & Q3 \\
\hline $5 \overline{52}$ & 1.104 & 1.652 & 2.208 \\
\hline
\end{tabular}

Skor yang diperoleh dari responden 1.731

Gambar 7. Kerberlanjutan Pertanian Berdasarkan Dimensi Kelembagaan tanian, penyalur hasil produk pertanian dan lembaga keuangan mikro (bank/koprasi) dinilai petani cukup tersedia dan berperan dalam mendukung kegiatan pertanian. Hasil temuan ini sejalan dengan hasil temuan Nurmalina (2008) \& Saida dkk. (2011) yang menemukan bahwa keberlanjutan sangat dipengaruhi keberadaan sistem kelembagaan yang berfungsi secara maksimal. Berdasarkan hal tersebut maka cukup logis jika ketersediaan sistem kelembagan yang menunjang kegiatan pertanian akan menjadi salah satu aspek yang mendukung keberlanjutan pertanian di lokasi penelitian.

Keberlanjutan pertanian berdasarkan dimensi teknologi

Aspek teknologi merupakan salah satu aspek penunjang dalam kegiatan pertanian. Oleh karena itu, analisis keberlanjutan dari sisi dimensi teknologi menjadi sangat penting untuk dilakukan. Analisis keberlanjutan pertanian dari sisi dimensi teknologi dalam penelitian ini dianalisis dari persepsi petani terhadap 6 (enam) atribut aspek teknologi yang terkait dengan kegiatan pertanian diantaranya adalah; (1) persepsi petani terhadap pengetahuan petani tentang teknik pengolahan tanah yang baik dan benar, (2) persepsi petani terhadap pengetahuan petani tentang teknologi konservasi tanah dan air, (3) persepsi petani terhadap pengetahuan petani tentang teknik penggunaan mulsa untuk meningkatkan kesuburan tanah, (4) persepsi petani terhadap pengetahuan petani tentang teknologi pembuatan pupuk organic dan obat-oabatan alami, (5) persepsi petani terhadap pengetahuan petani tentang teknologi pengolahan hasil produk pertanian untuk meningkatkan nilai tambah, dan (6) persepsi petani terhadap pengetahuan petani tentang teknologi pembuatan biopestisida. Pengukuran indikator dimensi teknologi menggunakan skala likerts dan dianalisis dengan metode kuartir (Q). Hasil pengukuran diperoleh nilai batas bawah sebesar 552, nilai batas atas sebesar 2.760 , nilai Q 1 sebesar 1.104, nilai Q2 sebesar 1.656 dan nilai Q3 sebesar 2.208, sedangkan nilai hasil survey lapangan yang diperoleh dari responden sebesar 1.745 yang berada di anatar Q1 dan Q2 (Gambar 8).

Keterangan:

Batas bawah s/d Q1 = Kerberlanjutan pertanian berdasar kan dimensi teknologi sangat rendah

$>$ Q1 $\mathrm{s} / \mathrm{d}<\mathrm{Q} 2=$ Kerberlanjutan pertanian berdasar kan dimensi teknologi rendah

$>$ Q2 $\mathrm{s} / \mathrm{d} \angle \mathrm{Q} 3=$ Kerberlanjutan pertanian berdasar kan dimensi teknologi tinggi

$>$ Q3 s $/$ d batas atas = Kerberlanjutan pertanian berdasar kan dimensi teknologi sangat tinggi

Hasil pengukuran pada Gambar 8 dimana nilai hasil survey berada di antara Q2 dan Q3 yang berarti dimensi teknologi mengarah kearah yang tinggi dalam mendukung keberlanjutan pertanian. Tingginya dimensi teknologi dalam 


\begin{tabular}{|c|c|c|c|c|}
\hline \multicolumn{3}{|c|}{ Keberlanjutan rendah } & \multicolumn{2}{|c|}{ Keberlanjutan tinggi } \\
\hline$B$ & $Q 1$ & $Q 2$ & Q3 & 1 \\
\hline $5 \overline{52}$ & 1.104 & 1.652 & 2.208 & $2.76 \mathrm{C}$ \\
\hline
\end{tabular}

Skor yang diperoleh dari responden 1.745

Gambar 8. Kerberlanjutan Pertanian Berdasarkan Dimensi Teknologi

mendukung keberlanjutan pertanian mengandung makna bahwa dari sisi pengetahuan, penguasaan maupun ketersedian teknologi yang terkait dengan pertanian sudah baik. Walaupun secara keseluruhan nilai hasil survey dimensi teknologi sudah tergolong baik, namun nilainya mendekati Q2 sehingga upaya peningkatan pengetahuan, penguasaan dan ketersedian teknologi teknologi pertanian harus terus ditingkatkan. Hasil temuan ini sejalan dengan hasil temuan Nurmalina (2008) \& Saida dkk. (2011) yang menemukan bahwa keberlanjutan pertanian sangat ditentukan oleh pengetahuan petani terhadap teknologi pertanian, ketersedian teknologi yang cukup dan mudah diakses. Fenomena ini memberikan gambaran bahwa pengetahuan dan penguasaan teknologi pertanian dalam mendukung keberlanjutan pertanian menjadi sangat penting.

\section{KESIMPULAN}

Hasil analisis daya dukung lahan pertainan di Desa Duren, baik melalui analisis kuantitatif maupun analisis kualitatif dari persepsi petani menunjukan sudah rendah. Walaupun daya dukunya pertaniannya sudah rendah, namun dari sisi keberlanjutan pertaniannya masih tergolong tinggi. $\mathrm{Hal}$ ini tampak dari pengukuran 5 (lima) dimensi keberlanjutan hanya 1 (satu) dimensi yang termasuk kategori rendah dalam mendukung keberlanjutan pertanian yaitu dimensi sosial, sedangkan untuk dimensi ekonomi, dimensi lingkungan, dimensi kelembagaan dan dimensi teknologi masih tergolong tinggi.

\section{UCAPAN TERIMAKASIH}

Pada kesempatan ini penulis mengucapkan banyak terima kasih kepada Program Studi Ilmu Lingkungan yang telah memberikan dana Penelitian Hibah Bersaing Sekolah Pascasarjan UGM Tahun 2019. Penulis juga, mengucapkan banyak terima kasih kepada Anggota Tim Peneliti yang telah berperan dalam penulisan laporan hibah. Tidak lupa penulis juga mengucapkan terimaksih kepada Asisten Lapangan yang telah membantu dalam mengumpukan data di lapangan.

\section{DAFTAR PUSTAKA}

Charles W. Lamb, Joseph F. Hair dan Carl McDaniel. 2001. Pemasaran. Edisi Pertama (terjemahan). Jakarta. Salemba Empat

Padjarajani S. (2008). Dinamika Masyarakat Dan Konversi Lahan
Pertanian Serta Pengaruhnya Terhadap Pengetahuan Tentang Lingkungan Di Kawasan Bandung Utara. Majalah Geografi Indonesia. Vol (22)2:102-123.

Gliessman S.R. The Framework for Conversion. In Gliessman, S.R and M. Rosemerey (eds.). (2010). The Conversion to Sustainable Agriculture, Principles, Process and Practices. CRC Press, New York.

Harington L.W. (1992). Rice Wheat Diagnostic Survey for Sustainable Agricultural: A Case Study in India. In Asian Farming System Symposium Sustainable Agricultural: Meeting the Challenge Today. 2-5 November. Colombo. Sri Langka

Hariyanto, Hadi, S.P. dan Buchori, I. (2018). The population growth and carrying capacity in Semarang City. E3S Web of Conference. https://doi.org/10.1051/e3sconf/20183107010. diakses hari Kamis, 18 April 2019.

Herlindawati A., I. Lucyana T. dan Trisna I.N. (2018). Analisis Tekanan Penduduk Terhadap Petani Padi Sawah (Suatu Kasus di Kecamatan Cilamaya Kulon, Kabupaten Karawang Jawa Barat). Jurnal Pemikiran Masyarak at Ilmiah Berwawasan Agribisnis.Vol 4(1): 12-24.

Husodo S. (2005) Penilaian Ekonomi Lahan dan Keberlanjutan Usahatani Di Kawasan Pinggiran Kota Yogyakarta, Disertasi. Yogyakarta. Sekola h Pascasarjana, Universitas Gadjah Mada.

Ismanto K., Huda H. M. dan Maulida C. (2012). Transformasi Masyarakat Petani Mranggen Menuju Masyarakat Industri. Jurnal Penelitian: Vol 9(1): 35-48.

Manik K.E.S. (2003). Pengelolaan Lingkungan Hidup. Penerbit Djambatan, Jakarta.

Mantra Ida B. (1986). Pengantar Studi Demografi. Yogyakarta: Nur Cahya.

Moniaga V.R.B. (2011). Analisis Daya Dukung Lahan Pertanian. Jurnal Agri Sosial Ekonomi 7(2): $61-68$

Muta'ali L. (2015). Teknik Analisis Regional. Yogyakarta. Badan Penerbit. Fakultas Geografi (BP FG).

Notohadiprawiro, T, Soekodarmodjo, S.dan Sukana, E. (2006). Pengelolaan Kesuburan Tanah dan Peningkatan Efisiensi Pemupukan. Yogyakarta. Universitas Gadjah Mada.

Nurmalina R. (2008). Analisis Indeks dan Status Keberlanjutan Sistem Ketersedian Beras di Beberapa Wilayah Indonesia. Jumal Agro Ekonomi. Vol (26)1:47-79.

Otsuka K. (2001). Population Pressure, Land Tenure, and Natural Resource Management. ADB Institute Working Paper. Diakses Tanggal 12 April 2019 dari https://www. adb.org/ sites/default/files/publication/157197/adbi-rp16.pdf

PSDL. (2013). Daya dukung lahan (Bahan Kajian Landuse Planning And Land Management). diakses 4 April 2019 dari https:// www.Smno.psdl.pdip.pdkl.ppsub.okt 2013 .

Prayoga K., Suryani N., Manna S, dan Adietya M. R. (2019). Menakar Perubahan Sosio-Kultural Masyarakat Tani Akibat Miskonsepsi Modernisasi Pembangunan Pertanian. Joumal on Socio-Economics of Agriculture and Agribusiness Vol.13 (1):96-114.

Putra I. D. G.A. D., Utama M. S. dan Yasa I. G.W. M. (2016). Analisis daya dukung lahan berdasarkan total nilai produksi pertanian di Kabupaten Giaynya. E-Jurnal Ekonomi Dan Bisbis Universitas Undayana. Vol 5(3): 387-402.

Ridwan N.A. (2007). Landasan Keilmuan Kearifan Lokal. Jurnal Studi Islam dan Budaya. Vol 5(1): 27-38.

Rivai R.S. dan Iwan S.A. (2011). Konsep Dan Implementasi Pembangunan Pertanian Berkelanjutan di Indonesia. Forum Penelitian Agro Ekonomi, Vol (29)1:13- 25.

Riyadi dan Bratakusumah (2004). Perencanaan Pembangunan Daerah. PT Gramedia Pustaka Uta ma. Jakarta.

Saida S., Sabiham dan Widiatmaka. (2011). Analisis Keberlanjutan Usahatani Hortikultura Sayuran Pada Lahan Berlereng Di Hulu Das Jeneberang, Sulawesi Selatan. Jurnal Matematika, Sains, dan Teknologi. Vol 12(2):101-112

Soemarwoto O. (1985). A Qualitative of Population Pressure and It's Potential Use in Development Planning. Majalah Demo- 
grafi Indonesia. Vol $12(24)$.

Soemarwoto O. (2001). Ekologi, Lingkungan dan Pembangunan. Jakarta: Djambatan.

Sudrajat. (2013). Tinjauan Spasial Komitmen Petani Mempertahankan Kepemilikan Lahan Sawah Dan Pemanfaatannya Untuk Pertanian Di Kabupaten Sleman Dan Bantul Daerah Istimewa Yogyakarta. Disertasi. Yogyakarta. Fakultas Geografi-UGM.

Sudrajat. (2015). Pemetaan Lahan Sawah Potensial Untuk Dimanfaatan Secara Berkelanjutan Di Kecamatan Godean Proseding Seminar Nasional Teknologi Terapan. Yogya ka rta. SV-UGM. Halaman: 79-83.

Sudrajat. (2016). Farmers Commitment In Maintaining Wetland Ownership Status In Peri-Urban Area Of Yogyakarta. Indonesia Journal of Geography. Vol (48)1: 91-101.

Sudrajat. (2018). Peranan Nilai-Nilai Kearifan Lokal Dalam Kegiatan Pertanian di Desa Banjararum Kecamatan Kalibawang. Kongres $I X$ \& PIT IGI XX. Manado. Universitas Negeri Menado.

Sudrajat. (2018). Analisis Ketidakpastian Dalam Memanfaatkan Lahan Pertanian Di Desa Sukasari Kaler Kecamatan Argapura Majalengka. Majalah Geogrofin Indonesia Vol (32)1:84 $-97$.

Suhartini. (2019). Kajian Kearifan Lokal Masyarakat dalam Pengelolaan Sumber Daya Alam dan Lingkungan. https:// eprints. uny. ac.id/12149/diakses Senin, 15 April 2019.

Sukayat Y. (2013). Perkembangan Pertanian Organik di Kabupaten Tasikmalaya. Dinas Pertanian Tanaman Pangan Kabupaten Tasikmalaya.
Sunarya S., Supriyanto dan Hudaidah. (2016). Perubahan Sosial Di Air Belo Kecamatan Muntok Kabupaten Bangka Barat (2000-2007). Jurnal Criksetra: Vol 5(9): 25-37.

Supardi I. (1994). Pembangunan Yang Memanfaatkan Sumber Daya. Jakarta. PT. Rineka Cipta.

Sutanto R. (2002). Pertanian Organik: Menuju Pertanian Alternatif dan Berkelanjutan. Yogyakarta. Kanisius.

Soerjani. (1987). Lingkungan: Sumber Daya Alam dan Kependudukan dalam Pembangunan. Jakarta. Jakarta. Penerbit. UI-Pres.

Suryanto. (2007). Informasi dan Pengetahuan. Diperoleh tanggal 1 Maret 2014 darihttp://www.suryanto.blogspot.co.id/html. diakses taggal 4 juli 2019.

Shepherd W.G. (1998). The Economic of Industrial Organization (New Jersey): Prentice-Hall.

Talumingan C. dan Jocom S.G. (2017) Kajian Daya Dukung Lahan Pertanian Dalam Menunjang Swasembada Pangan Di Kabupaten Minahasa Selatan. Jurnal Agri-Sosioekonomi, Vol (13) $1: 11-24$.

Trisilia M., Henny P. dan Suci A. (2014). Pemodelan Daya Dukung Lahan Pertanian Pangan Dengan Model Spasail Autoregressive (SAR) di Kota Batu. Jurn al Natural B. 2(4):396-401.

Untung K. (1989). Pembangunan Petanian Berkelanjutan Dalam Persaingan Lingkungan Global dan Penggunaan sumberdaya Optimal, http://kasumbogo. staff.ugmacid/ detailrticle.phpmesid=34erkata_kunci =pertanian\% 20berkelanjutan\% 20PHT \% 20p; diakses Senin, 6 Agustus 2009 .

Zamroni M. I. (2010). Perubahan Sosial-Budaya Petani Organik Di Yogyakarta. Jurnal Masyarakat es Budaya: Vol 12(1): 71-92. 